\title{
Detailed quantitative method in microvertebrate taphonomy in the case of Pleistocene filling of the Vaskapu II rock shelter
}

\author{
András Szabolcs Sóron \\ Department of Physical and Applied Geology, \\ Eötvös Loránd University, Budapest
}

\author{
Attila Virág \\ Department of Palaeontology, \\ Eötvös Loránd University, Budapest
}

\begin{abstract}
A total of 1,514 fossil bones were studied from the Vaskapu II rock shelter (Bükk Mountains, North Hungary). The objective of this study was to investigate those processes of bone modification that were important in the dispersal, destruction and preservation of bone in the deposit. Size-selective taphonomic processes were detected in the accumulation of vertebrate remains. The fossils were transported by water through a $15 \mathrm{~m}$ high fissure system above the locality during repeated precipitation and thawing. Size-sorting of the bones occurred within the fissures. During this process the fossils were damaged and fragmented and the remains were eventually emplaced into the Vaskapu II rock shelter. The size-sorting is statistically established by a method based on the chisquare test. This method clearly describes the differences between the life and death assemblages.
\end{abstract}

Key words: Vertebrate taphonomy, Late Pleistocene, Vaskapu II rock shelter, Bükk Mountains, cave sediments

\section{Introduction}

To infer the correct paleoecological environment it is important to distinguish the original biocoenosis and taphocoenosis of a fossil site. The basis of modern vertebrate taphonomy was developed by Andrews $(1990,1992,1995)$ and Lyman (1994). A few but essential articles can be found on similar taphonomic studies dealing with Hungarian material (e.g. Mészáros 1999a; Kordos and Begun 2001; Bernor et al. 2004; Amour-Chelu et al. 2005). In this article we attempt to develop a method which clearly describes the differences between the life and death assemblages, thus a well-known taphonomically-mixed assemblage was chosen.

Addresses: A. Sz. Sóron, A. Virág: H-1117 Budapest, Pázmány P. sétány 1/c, Hungary. e-mail: soron@caesar.elte.hu,virag@caesar.elte.hu

Received: September 26, 2009; accepted: November 15, 2009 
A similar approach was used previously by $\operatorname{Kos}(2001,2003 a, 2003 b)$ on a vertebrate assemblage from a pitfall cave fossil deposit in southeastern Australia. Another aim of our study was to improve a method for investigating sizeselective taphonomic processes. To develop this method the following conditions must be met:

1. On the basis of the previous studies concerning the examined locality it can be presumed that the original biocoenosis and the taphocoenosis differ.

2 . The locality can yield abundant material, which means it can produce an adequate amount of data.

Microvertebrate remains are frequent in Pleistocene sediments of Hungary. The clay filling of the Vaskapu II rock shelter (Bükk Mountains, North Hungary) was considered adequate for the purposes of the proposed study because of its well-known, previously documented taphonomically-mixed fauna (Mészáros 1999b).

\section{Locality}

The Bükk Mountains is one of the major karst zones in North Hungary, where numerous caves and fissures yielded abundant Pleistocene vertebrate fossil material. The Vaskapu II rock shelter is located $5 \mathrm{~km}$ from Felsőtárkány, on the west side of the Lök Valley (Bükk Mountains, North Hungary) (Fig. 1). The previous studies (except from Mészáros 1999b) focused on the Vaskapu Cave but the rock shelters near the cave are filled with the same red clay sediment and connected to the cave through a branching fissure system.

The aims of the earlier paleontological studies from the Vaskapu II rock shelter were to determine the taxonomical groups, define the age of the fauna and draw paleoecological inferences (Kadić and Mottl 1938; Kadić 1952; Hír 1994). Mészáros $(1999 b, 2004)$ correlated the locality with the Upper Pleistocene (Upper Würm, Pilisszántó Horizon, about 15,000 years B.P.) by the occurrence of Sorex alpinus. Válóczi (1999) reconstructed the paleoclimatological conditions according to the 'vole-thermometer' method, developed by Kordos (1978), but the latter paleoecological reconstruction probably achieved incorrect results because it ignored the complicated taphonomic settings of the locality.

\section{Material and methodology}

\section{Material}

Eight samples of $0.5 \mathrm{~kg}$ were collected from the Vaskapu II rock shelter. The host rock is reddish brown clay with limestone fragments. The collected material was treated by hydrogen peroxide and was washed through a $0.5 \mathrm{~mm}$ sieve. A Nikon SMZ 800 binocular microscope, Nikon Coolpix 4500, Nikon D70 and Canon EOS 300D digital cameras were used for the documentation. A total of 1,109 limb bones from the Vaskapu II rock shelter and a total of 7,980 limb bones 
Fig. 1

Locality map of the Vaskapu II rock shelter

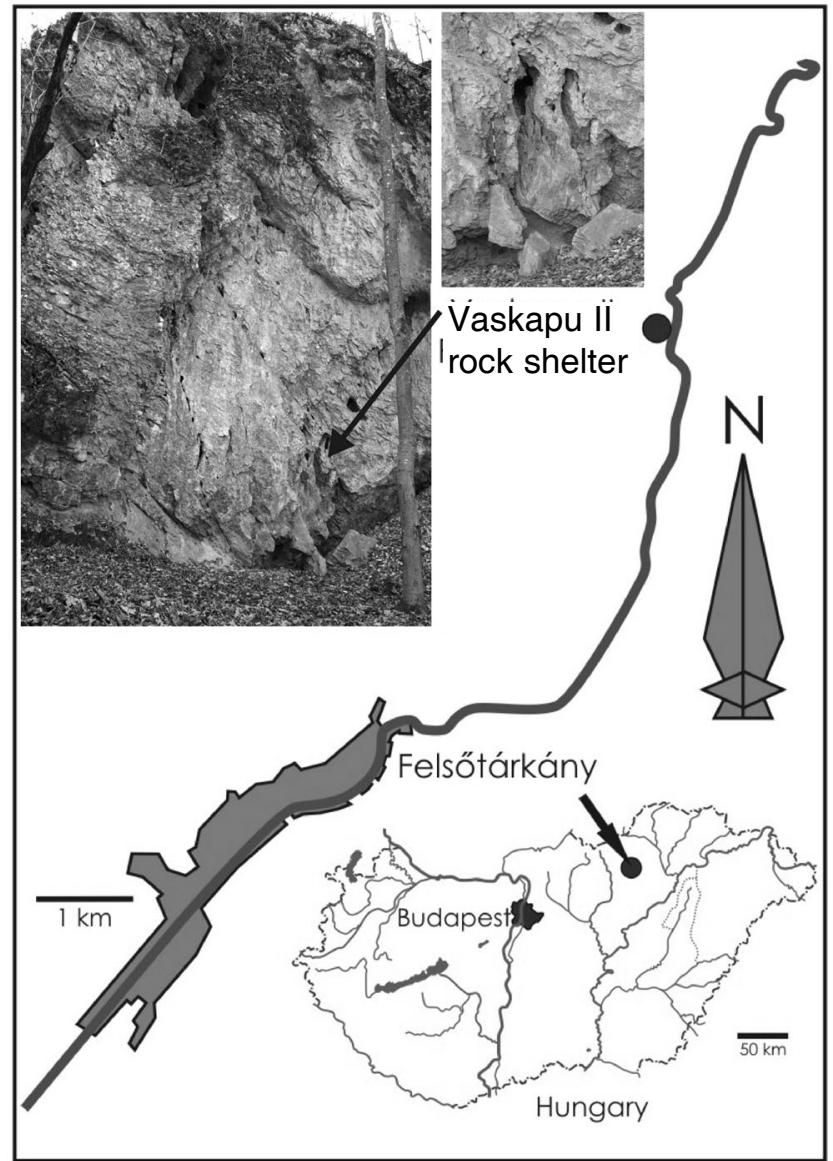

of 70 specimens of 10 recent small mammal species from the Mammalia Collection of Hungarian Natural History Museum were measured for the sizeselectivity analysis. The taxonomic identification of the specimens was based on the encountered 405 teeth and cranial elements. Osteichthyes indet., Anura indet., Lacertilia indet., Serpentes indet., Aves indet., Chiroptera indet., Sorex sp., the Apodemus sylvaticus-flavicollis group, Cricetus cricetus, Myodes glareolus, Arvicolidae indet., Microtus gregalis, Microtus arvalis, Microtus agrestis, and Mustelidae indet. were identified from the Vaskapu II locality.

\section{Investigation of bone modifications}

The bone surface modifications (splitting, flaking, pitting) were examined using a binocular microscope. The interpretation of the modifications was based upon earlier studies of Andrews (1990) and Kos (2003a). The magnification depended on the scale of the modification. Splitting is defined as very fine 
fissures on the bone surface. Flaking is defined as imperfection of bone surface that commonly spread out from breaks and splits in the bone. Pitting is defined as any feature that penetrated the bone surface resulting in depression-like structures.

Fracture types of tubular bones

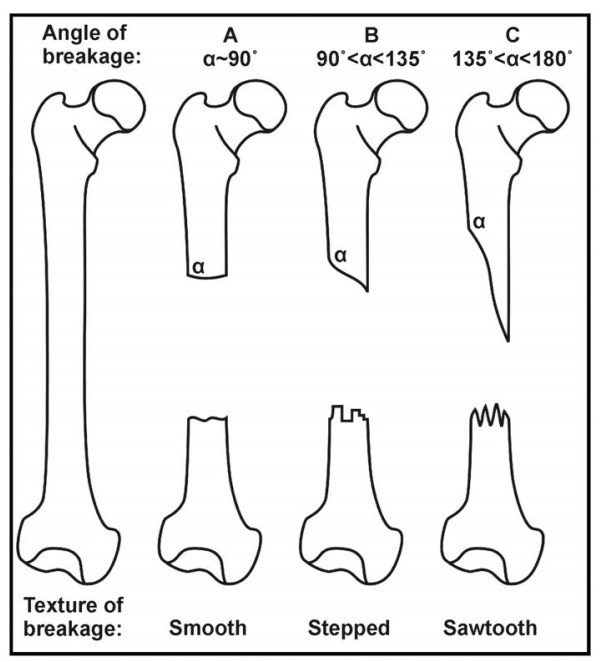

Fig. 2

Fracture types of tubular bones (modified after Shipman et al. 1981)

The fracture type of tubular bones (Fig. 2) was categorized by Shipman et al. (1981) and Kos (2003a) on the basis of the angle and the texture of the broken surface. The A-type breakage is characteristic of mineralized bones. The non-fossilized bones show breaking type C. Breaking type B is a transition between A and C. Sawtoothtype breakage is typical for recent or non-mineralized bones. Stepped breaking texture appears on dried or semi-fossilized remains. Smooth texture is typical of fossilized bones or destroyed breakage. We used the method from Kos (2003a).

\section{Fracture types of cranial elements}

Fracture types of cranial elements are shown in Fig. 3. The examination of cranial elements indicates the degree of distraction and it implies the manner of accumulation. There are two approaches to describe breakage categories of the remains: what is present or what is lost. In this article we used the first approach.

Skull breakage categories (modified after Kos 2003a):

A: Almost complete skull with or without occipital and parietal bone.

B: Anterior half maxilla with premaxilla.

C: Maxilla with most of zygomatic arc.

D: Maxilla without zygomatic arc.

E: Broken maxilla with teeth or alveoli.

F: Only premaxilla present.

G: Isolated zygomatic arc fragments.

Mandible breakage categories (modified after Kos 2003a):

A: Complete mandible with no breakage. 
B: Minor breakage of coronoid, articular or angular process.

C: Corpus mandibulae present without ascending ramus.

D: Anterior part of mandible and ascending ramus are absent.

E: Only anterior part of mandible present.

F: Only ascending ramus present.

G: Broken corpus mandibulae with teeth or alveoli.

$\mathrm{H}$ : Only anterior part of mandible present with major breakage, inferior border is broken, incisor is exposed.

I: Isolated coronoid, articular and angular process fragments.

Number of identified specimens (NISP) and minimum number of individuals (MNI)

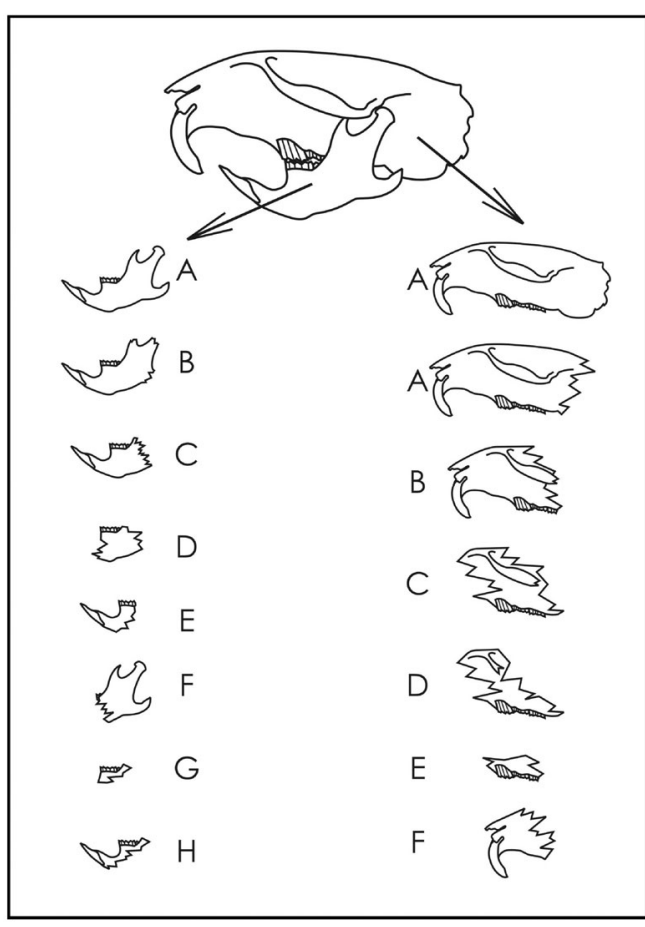

The number of identified specimens (NISP) and the minimum number of individuals (MNI) are the most essential

Fig. 3

Mandible (left column) and skull (right column) breakage categories (see explanation in text) (modified after Kos 2003) features of an assemblage (Andrews 1990; Kos 2003a). NISP is the potential maximum number of the collected specimens, thus it is equal to the number of the collected specimens (405 teeth and cranial elements $+1,109$ limb bones $=1,514$ in the case of the Vaskapu II rock shelter). To calculate MNI only those bones were considered which possibly belonged to one skeleton. The ratio of MNI and NISP represents the relative abundance of bones which definitely belonged to one specimen.

\section{Relative abundance of skeletal elements}

The relative abundance of skeletal elements is expressed by the ratio of found and expected remains (modified after Andrews 1990; Kos 2003a).

$$
R_{i}=\frac{N_{i}}{M e_{i} \times E_{i}} \times 100
$$

where $R_{i}$ is the relative abundance of the examined skeletal element in the sample, $N_{i}$ is the number of the examined element in the sample, $M e_{i}$ is the MNI 
of the examined element in the sample and $E_{i}$ is the total number of the examined element in the skeleton.

\section{Relative abundance of the fractures of tubular bones}

The relative abundance of the fractures of tubular bones is determined by the number of the intact bones and the distal and proximal fragments. The number of diaphyseal fragments is not included because some of them could have belonged to the same bone (Andrews 1990; Kos 2003a). Breakage divisions (proximal epiphysis, distal epiphysis, diaphysis) of limb bones are shown in Fig. 4.

$$
R_{i}=\frac{P_{i}+D_{i}}{N_{i}} \times 100
$$

where $R_{i}$ is the relative abundance of the examined skeletal element in the sample, $P_{i}$ is the number of proximal elements found in the sample, $D_{i}$ is the number of distal elements found in the sample, $N_{i}$ is the number of intact bones in the sample.

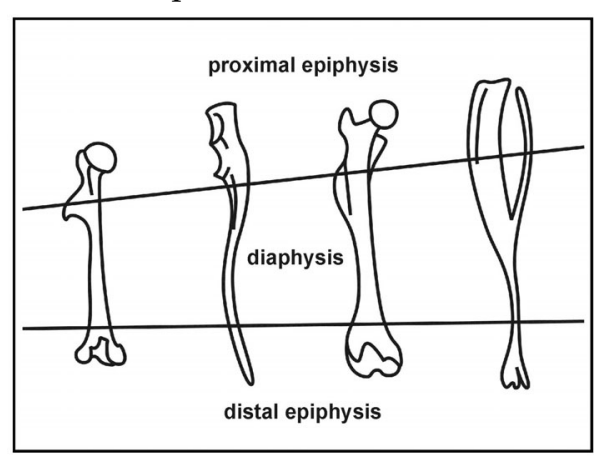

Fig. 4

Breakage divisions of major limb bones (modified after Andrews 1990)

The result reveals data about disruption of the assemblage. If $R_{i}$ is greater than 100, the number of intact bones exceeds the number of broken elements.

\section{Teeth and alveoli}

The relative abundance of isolated molars is exposed by the ratio of the number of isolated molars found and the number of empty alveolar spaces (Kos 2003a).

$$
R_{i}=\frac{M_{i}}{A_{i}} \times 100
$$

where $R_{i}$ is the relative abundance of isolated molars of the examined taxon in the sample, $M_{i}$ is the number of isolated molars found in the sample, $A_{i}$ is the number of empty alveolar spaces in the sample.

The result provides data about distraction of the assemblage. If $R_{i}$ is less than 100 the isolated molar loss is regarded as significant.

The relative abundance of molar loss is determined by the number of the empty and tooth-bearing molar alveoli (Andrews 1990; Kos 2003a).

$$
R_{i}=\frac{A_{i}}{A_{i}+M_{i}} \times 100
$$


where $R_{i}$ is the relative abundance of molar loss of the examined taxon in the sample, $A_{i}$ is the number of empty alveolar spaces found in the sample, $M_{i}$ is the number of tooth-bearing alveoli found in the sample.

The relative abundance of mandibular and maxillary molar loss may be determined separately in samples with abundant material.

The preservation index of maxilla and mandible is expressed by the number of molar alveoli found and absent (modified from Kos 2003a).

$$
R_{i}=\frac{A_{i}+M_{i}}{N_{i} \times E_{i}} \times 100
$$

where $R_{i}$ is the preservation index of the examined taxon in the sample, $A_{i}$ is the number of empty alveolar spaces found in the sample, $M_{i}$ is the number of toothbearing alveoli found in the sample, $N_{i}$ is the number of cranial elements of the examined taxon with molar alveoli found in the sample, $E_{i}$ is the total number of alveolar spaces of the examined taxon in a complete tooth-bearing cranial element.

The result provides data about disruption of the assemblage. Lower values mean higher degradation of the tooth-bearing cranial elements.

\section{New method for investigating size-selective taphonomic processes}

The aforementioned equations are useful to describe a taphocoenosis, whereas other methods are needed to statistically determine size-selective taphonomic processes. Our method clearly describes the differences between the life and death assemblages.

A total of 7,980 limb bones of 70 specimens of 10 recent small mammal species were measured. Size frequency distribution diagrams of the bones of some frequent Pleistocene small mammals were made from these measurements of each studied species. Every distribution was derived from three selected specimens (average adult size, below average and over average). Size-selectivity can be proved by mathematical-statistical tests. The size frequency distribution of the limb bones in the fossil sample was compared with a theoretical distribution, which contains all the limb bones of all specimens in proportion of the percentage distribution of the identified taxa on the basis of cranial elements. It can be calculated from the diagrams in Fig. 5 and Fig. 6 by this equation:

$$
X_{i}=\sum_{s=1}^{n}\left(p_{s} \times r_{i}\right)
$$

where $X_{i}$ is the number of limb bones in the theoretical distribution in size bin $i$, $p_{s}$ is the percentage abundance of the examined taxon in proportion to all identified species on the basis of cranial elements, $r_{i}$ is the number of limb bones in size bin $i$ of the examined taxon in the sample. 

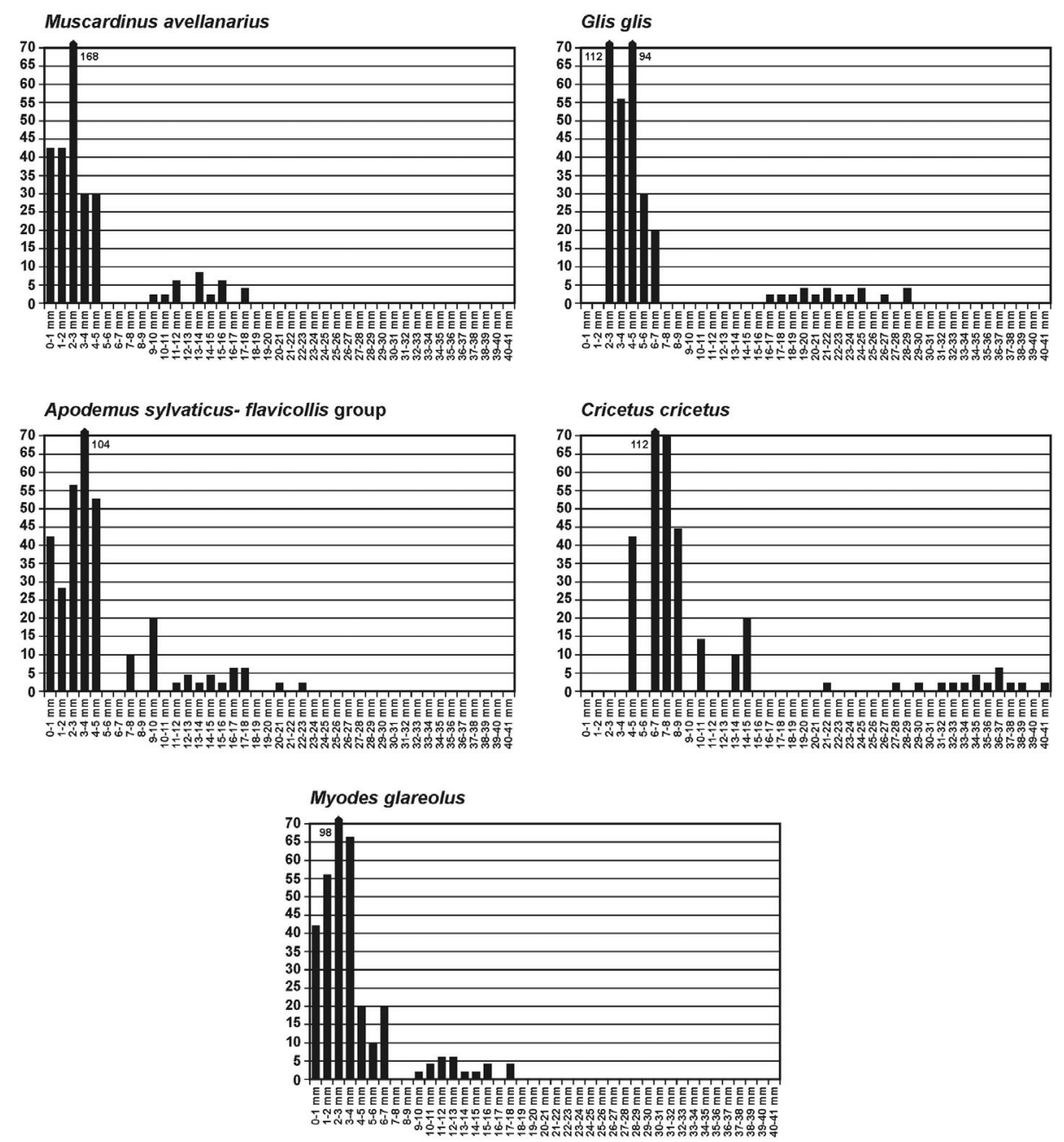

Fig. 5

Size frequency distributions of some frequent Pleistocene small mammals I

The size-selectivity analysis is based on the $\chi^{2}$ (chi-square) test. This statistically tests whether the distribution $\mathrm{F}$ of the variants $\xi$ is a distribution characterized by the distribution function $\mathrm{F}_{0}$ (null hypothesis). The null hypothesis is that the life and death assemblages do not differ. A critical value $\left(\chi^{2}{ }_{n-1}(\alpha)\right)$ can be determined by the $\chi^{2}$ distribution table (Table 1.). If the result is more than the critical value, then the null assumption is false at significance level 1- $\alpha$. The equation used to compare the theoretical distribution and the fossil remains from the Vaskapu II rock shelter is as follows: 

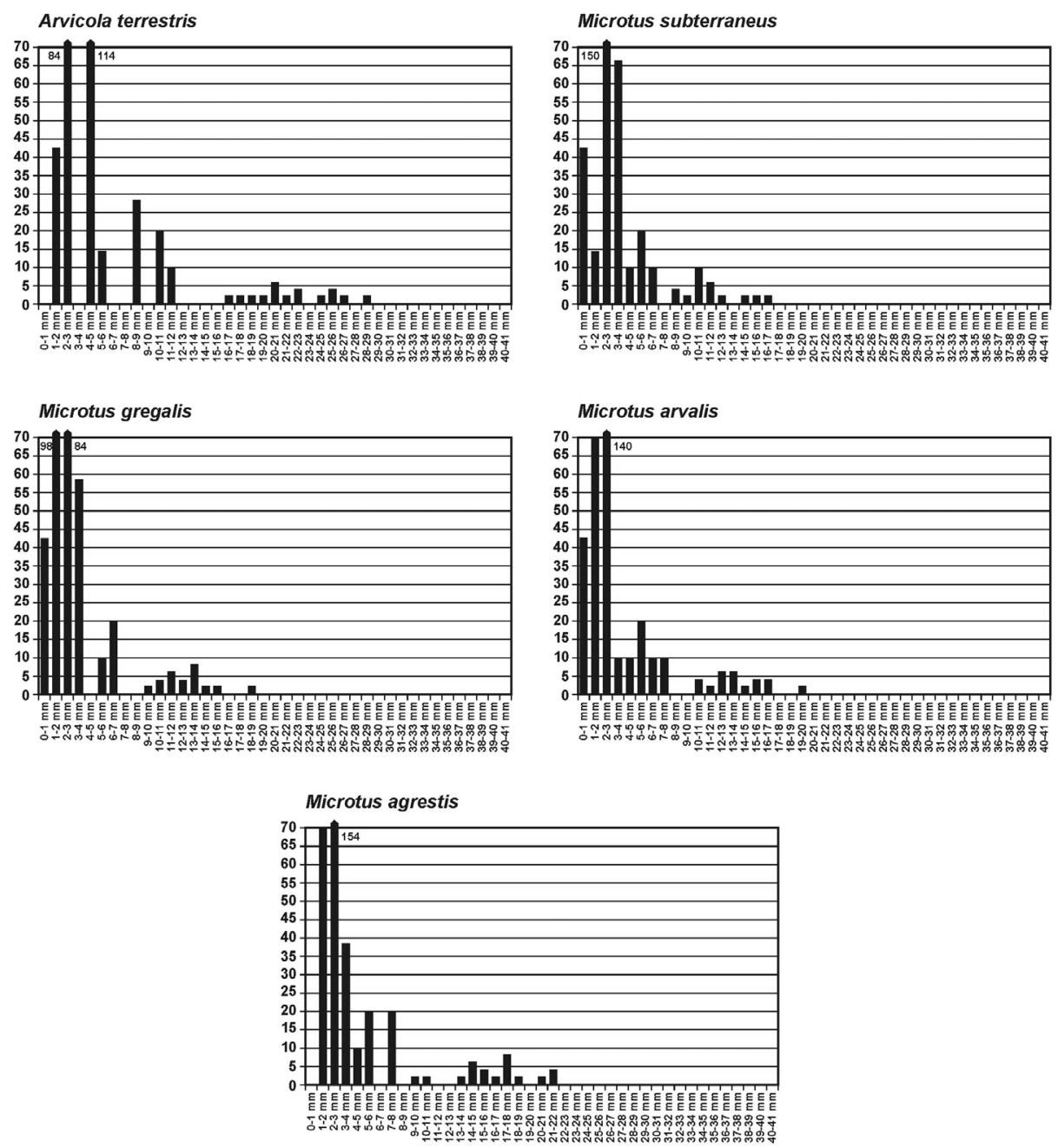

Fig. 6

Size frequency distributions of some frequent Pleistocene small mammals II

$$
\chi^{2}=n_{1} \times n_{2} \times \sum_{i=1}^{n} \frac{\left(\frac{v_{i}}{n_{1}}-\frac{\mu_{i}}{n_{2}}\right)^{2}}{v_{i}+\mu_{i}}
$$

where $\mathrm{n}_{1}, \mathrm{n}_{2}$ are the number of bones in the two distributions; $v_{i}, \mu_{\mathrm{i}}$ are the number of bones which pertain to category $i$ in the two distributions.

The result can be interpreted together with taphonomical investigations. It may be compared with other results from other fossil deposits. 
Table 1

The $\chi^{2}$ distribution table

\begin{tabular}{|c|c|c|c|c|c|c|c|c|c|c|c|c|c|}
\hline$\alpha$ & 0.005 & 0.01 & 0.025 & 0.05 & 0.10 & 0.25 & 0.50 & 0.75 & 0.90 & 0.95 & 0.975 & 0.99 & 0.995 \\
\hline$\overline{n-1}$ & & & & & & & & & & & & & \\
\hline 1 & 0.00 & 0.00 & 0.00 & 0.00 & 0.02 & 0.10 & 0.46 & 1.32 & 2.71 & 3.84 & 5.02 & 6.63 & 7.88 \\
\hline 2 & 0.01 & 0.02 & 0.05 & 0.10 & 0.21 & 0.58 & 1.39 & 2.77 & 4.61 & 5.99 & 7.38 & 9.21 & 10.6 \\
\hline 3 & 0.07 & 0.12 & 0.22 & 0.35 & 0.58 & 1.21 & 2.37 & 4.11 & 6.25 & 7.81 & 9.35 & 11.3 & 12.8 \\
\hline 4 & 0.21 & 0.30 & 0.48 & 0.71 & 1.06 & 1.92 & 3.36 & 5.39 & 7.78 & 9.49 & 11.1 & 13.3 & 14.9 \\
\hline 5 & 0.41 & 0.55 & 0.83 & 1.15 & 1.61 & 2.67 & 4.35 & 6.63 & 9.24 & 11.1 & 12.8 & 15.1 & 16.7 \\
\hline 6 & 0.68 & 0.87 & 1.24 & 1.64 & 2.20 & 3.45 & 5.35 & 7.40 & 10.6 & 12.6 & 14.4 & 16.8 & 18.5 \\
\hline 7 & 0.99 & 1.24 & 1.69 & 2.17 & 2.83 & 4.25 & 6.35 & 9.40 & 12.0 & 14.1 & 16.0 & 18.5 & 20.3 \\
\hline 8 & 1.34 & 1.65 & 2.18 & 2.73 & 3.49 & 5.07 & 7.34 & 10.2 & 13.4 & 15.5 & 17.5 & 20.1 & 22.0 \\
\hline 9 & 1.73 & 2.09 & 2.70 & 3.33 & 4.17 & 5.90 & 8.34 & 11.4 & 14.7 & 16.9 & 19.0 & 21.7 & 23.6 \\
\hline 10 & 2.16 & 2.56 & 3.25 & 3.94 & 4.87 & 6.74 & 9.34 & 12.5 & 16.0 & 18.3 & 20.5 & 23.2 & 25.2 \\
\hline 11 & 2.60 & 3.05 & 3.82 & 4.57 & 5.58 & 7.58 & 10.3 & 13.7 & 17.3 & 19.7 & 21.9 & 24.7 & 26.8 \\
\hline 12 & 3.07 & 3.57 & 4.40 & 5.23 & 6.30 & 8.44 & 11.3 & 14.8 & 18.5 & 21.0 & 23.3 & 26.2 & 28.3 \\
\hline 13 & 3.57 & 4.11 & 5.01 & 5.89 & 7.04 & 9.30 & 12.3 & 16.0 & 19.8 & 22.4 & 24.7 & 27.7 & 29.8 \\
\hline 14 & 4.07 & 4.66 & 5.63 & 6.57 & 7.79 & 10.2 & 13.3 & 17.1 & 21.1 & 23.7 & 26.1 & 29.1 & 31.3 \\
\hline 15 & 4.60 & 5.23 & 6.26 & 7.26 & 8.55 & 11.0 & 14.3 & 17.2 & 22.3 & 25.0 & 27.5 & 30.6 & 32.8 \\
\hline 16 & 5.14 & 5.81 & 6.91 & 7.96 & 9.31 & 11.9 & 15.3 & 19.4 & 23.5 & 26.3 & 28.8 & 32.0 & 34.3 \\
\hline 17 & 5.70 & 6.41 & 7.56 & 8.67 & 10.1 & 12.8 & 16.3 & 20.5 & 24.8 & 27.6 & 30.2 & 33.4 & 35.7 \\
\hline 18 & 6.26 & 7.01 & 8.23 & 9.39 & 10.9 & 13.7 & 17.3 & 21.6 & 26.0 & 28.9 & 31.5 & 34.8 & 37.2 \\
\hline 19 & 6.84 & 7.63 & 8.91 & 10.1 & 11.7 & 14.6 & 18.3 & 22.7 & 27.2 & 30.1 & 32.9 & 36.2 & 38.6 \\
\hline 20 & 7.43 & 8.26 & 9.59 & 10.9 & 12.4 & 15.5 & 19.3 & 23.8 & 28.4 & 31.4 & 34.2 & 37.6 & 40.0 \\
\hline
\end{tabular}

\section{Results and discussion}

The most important taphonomic parameters of the studied assemblage are shown in Fig. 7. Splitting and flaking, resulting from weathering and drying, is frequent on the examined bone surfaces. Splitting is commonly parallel to the orientation of collagen fibers in the bones. Relative abundance of the fractures of tubular bones is $159 \%$ (the fragments were compared with the total number of intact bones). The cranial elements are intensely fragmented. Fracturing occurred during transportation and redeposition.

Size-selective processes were unambiguously visible in the studied vertebrate assemblage. The fossils were transported by water through a $15 \mathrm{~m}$ high fissure system above the locality during repeated precipitation and thawing. Sizesorting of the bones occurred within the fissures. During this process the fossils were damaged and fragmented and the remains were finally emplaced into the Vaskapu II rock shelter. The size-sorting is statistically established by a method based on chi-square test. A total of 1,109 limb bones from the Vaskapu II rock shelter was measured for the analysis. The abundance of small-mammal species

Fig. $7 \rightarrow$

The taphonomic parameters of the Vaskapu II rock shelter (see further information in the explanation of mathematical methods) 

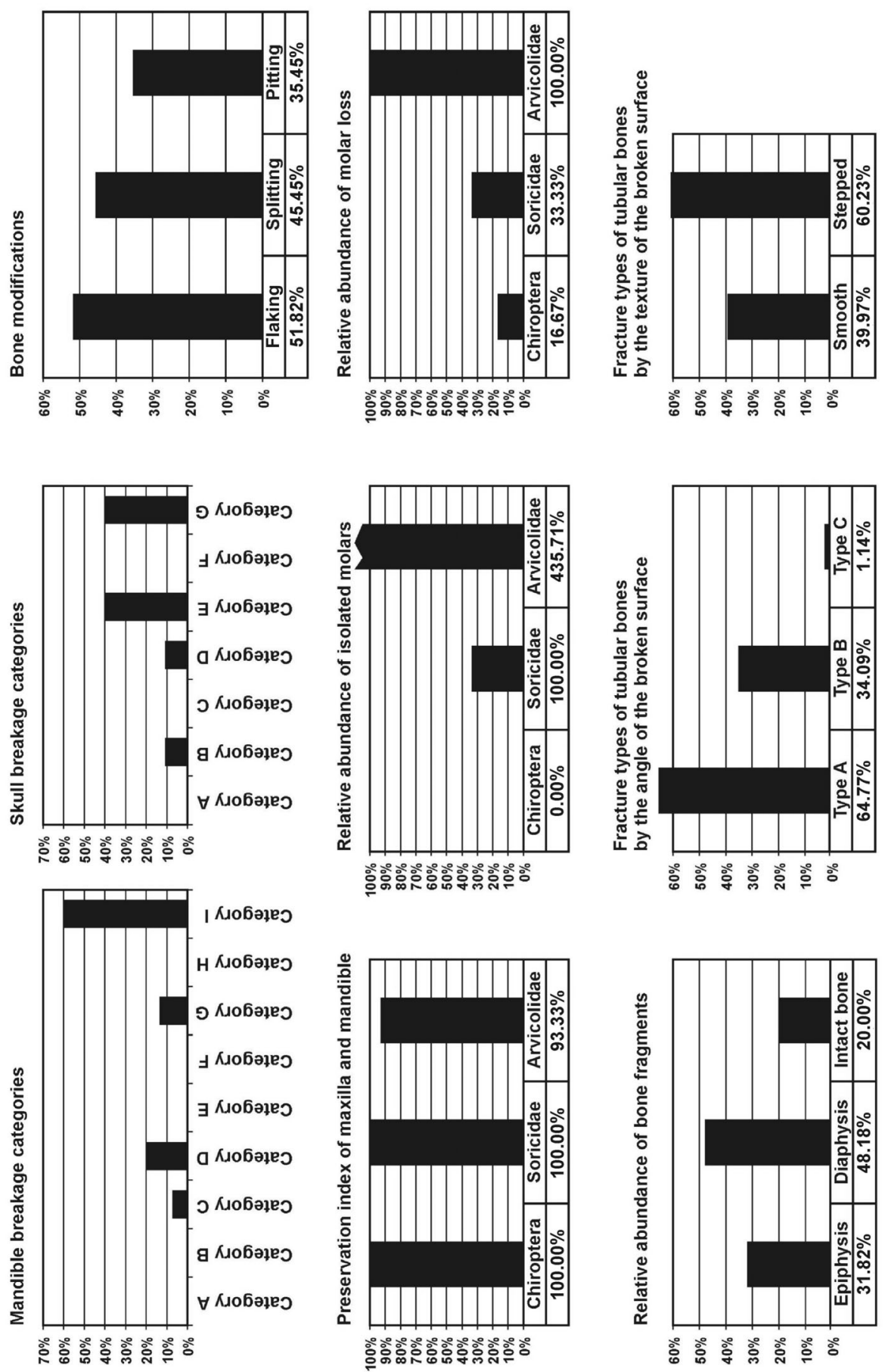

Central European Geology 52, 2009 
on the basis of cranial elements amongst all taxa which could be identified on a species level is the following: 7.9\% Apodemus sylvaticus-flavicollis group, $1.1 \%$ Cricetus cricetus, 5.6\% Myodes glareolus, 68.6\% Microtus gregalis, 15.7\% Microtus arvalis, $1.1 \%$ Microtus agrestis. The theoretical distribution was obtained from the size frequency distributions of some frequent Pleistocene small mammals (Fig. 5 and Fig. 6; the selection of these species was not restricted to the specimens from Vaskapu II rock shelter) and the abundance of small-mammal species on the basis of cranial elements in the fossil sample using equation (6). The size-frequency distribution of the limb bones from the locality (Fig. 8A) was derived from measured data. The theoretical distribution (Fig. 8B) was reduced to 1,109 bones, like the measured fossil bones from the Vaskapu II rock shelter, because of the comparability of the two distributions. Columns with a dotted pattern on the theoretical diagram represent the small bones (metacarpi, metatarsi, carpi, tarsi, phalanges) whereas columns with solid fill represent the long limb bones (humeri, radii, ulnae, femora, tibiae, fibulae). Clearly the fossil sample (Fig. 8B) contains fewer long bones (columns with solid fill) because of the cracking during the size-selective taphonomic processes. The addition of fragmented bones

\section{A - Theoretical distribution}

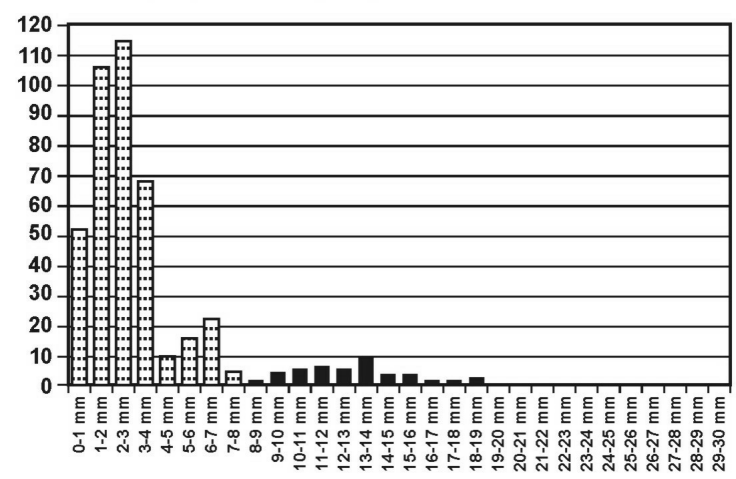

B - Measured data

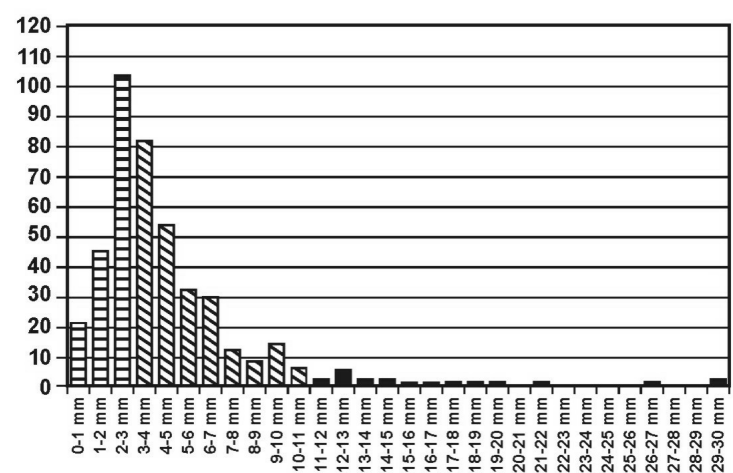

Fig. 8

Diagrams for investigating sizeselective taphonomic processes in the Vaskapu II rock shelter (see explanation in text) 
increases the value of medium size bins (columns with diagonal hachure pattern). The decrease of the number of short bones (columns with horizontal hachure pattern) can be explained by destruction during the process and further transport of these elements over longer distances; thus these fragments or tiny bones and teeth are washed out from the Vaskapu II rock shelter. The latter mechanism could be the explanation of the reduced number or total absence of tiny teeth of Chiroptera and Soricidae. The comparison of the distribution shown on the diagrams was made by the chi-square test. Equation (7) yields a $\chi^{2}$ value of 345.63 , which reveals a statistically significant difference between the life and death assemblages. The suggested reason of the difference is the breakage and size-sorting of the bones during transport through the fissure system.

It is proved that the taphocoenosis in the Vaskapu II rock shelter does not reflect the original biocoenosis. Therefore caution is needed in drawing paleoecological inferences on the basis of the proportion of fossil taxa. Otherwise the presence of some taxa provides paleoecological information. Faunal elements of the forest habitat (Glis glis, Apodemus sylvaticus-flavicollis group, Myodes glareolus) and the grassland habitat (Cricetus cricetus, Microtus arvalis, Microtus agrestis) occur together. The taxa which indicate cold climate (Microtus gregalis, Microtus nivalis; the latter was described from the site by Kadić and Mottl 1938) are relatively frequent. The occurrence of Rangifer tarandus (this taxon was described from the site by Kadić and Mottl 1938) indicates that the border of the taiga and the tundra was near the locality approximately 15,000 years B.P.

\section{Acknowledgements}

We would like to express our thanks to Lukács Mészáros, Miklós Kázmér, József Pálfy, Andrea Mindszenty, János Hír, László Kordos and Mihály Gasparik for their useful advice. Sincere thanks go to Gábor Csorba who made recent specimens available to us. We are grateful to József Kovács and Ilona Kovács-Székely for their help in expanding the statistical methods. Thanks are due to Emese Bodor and Ádám Csorba for their help. We are indebted to the Department of Paleontology and the Department of Physical and Applied Geology (Eötvös Loránd University, Budapest) for their encouragement. This work was supported by grant No. F-038041 of the National Scientific Research Fund.

\section{References}

Andrews, P. 1990: Owls, Caves and Fossils. - Natural History Museum Publications, London, 239 p. Andrews, P. 1992: The basis for taphonomic research on vertebrate fossils. - Conferencias de la Reunión de Taphonomía y Fosilización, Madrid, pp. 33-43.

Andrews, P. 1995: Experiments in taphonomy. - Journal of Archaeological Science, 22, pp. 147-153.

Armour-Chelu, M., P. Andrews, R.L. Bernor 2005: Further observations on the primate community at Rudabánya II (late Miocene, early Vallesian age), Hungary. - Journal of Human Evolution 49, pp. 88-98. 
Bernor, R.L., L. Kordos, L. Rook, J. Agustí, P. Andrews, M. Armour-Chelu, D.R. Begun D.W. Cameron, J. Damuth, G. Daxner-Höck, L. de Bonis, O. Fejfar, N. Fessaha, M. Fortelius, J. Franzen, M. Gasparik, A. Gentry, K. Heissig, G. Hernyak, T. Kaiser, G.D. Koufos, E. Krolopp, D. Jánossy, M. Llenas, L. Mészáros, P. Müller, P. Renne, Z. Rocek, S. Sen, R. Scott, Z. Szyndlar, Gy. Topál, P.S. Ungar, T. Utescher, J.A. van Dam, L. Werdelin, R. Ziegler 2004: Recent Advances on Multidisciplinary Research at Rudabánya, Late Miocene (MN9), Hungary: a compendium. Palaeontographia Italica, 89, pp. 3-36.

Hír, J. 1994: Jelentés a bükki Lök-völgyi-barlang, Vaskapu-barlang, valamint a kelet-cserháti Betyárbarlang 1994-évi kutatásáról. [The results of the palaeontological excavations in the Lök-völgyi Cave, Vaskapu Cave (Bükk Mountains) and in the Betyár Cave (Cserhát Mountains)]. - Bükk National Park, Eger, Manuscript, 6 p.

Kadic, O. 1952: A Kárpáti medence barlangjai (Magyarország, Csehszlovákia és Románia területén előforduló barlangok ismertetése), I. rész (Mai Magyarország). [Caves of the Carpathian Basin (Brief description of caves of Hungary, Czechoslovakia and Rumania). Part I. Hungary]. Geological Institute of Hungary, Budapest, Manuscript, 415 p.

Kadic, O., M. Mottl 1938: Felsőtárkány vidékének barlangjai. (Caves of the surrounding area of Felsőtárkány). - Barlangkutatás, 16/1, pp. 56-70.

Kordos, L. 1978: Changes in the Holocene climate of Hungary reflected by the 'vole-thermometer' method. - Földrajzi Közlemények, 25, pp. 222-229.

Kordos, L., D.R. Begun 2001: Primates from Rudabánya: allocation of specimens to individuals,next term sex and age categories. - Journal of Human Evolution, 40/1, pp.17-39.

Kos, A.M. 2001: Stratigraphy, sedimentary development and palaeoenvironmental context of a naturally accumulated pitfall cave deposit from southeastern Australia. - Australian Journal of Earth Sciences, 48, pp. 621-632.

Kos, A.M. 2003a: Characterisation of post-depositional taphonomic processes in the accumulation of mammals in a pitfall cave deposit from southeastern Australia. - Journal of Archaeological Science, 30, pp. 781-796.

Kos, A.M. 2003b: Pre-burial taphonomic characterisation of a vertebrate assemblage from a pitfall cave fossil deposit in southeastern Australia. - Journal of Archaeological Science, 30, pp. 796-779.

Lyman, R.L. 1994: Vertebrate taphonomy. - Cambridge University Press, Cambridge, 524 p.

Mészáros, L.Gy. 1999a: Néhány tafonómiai megfigyelés magyarországi felső-miocén Soricidae (Mammalia) maradványokon [Taphonomical observations on Late Miocene Soricids (Mammalia)]. - Földtani Közlöny, 129/2, pp. 159-178.

Mészáros, L.Gy. 1999b: Uppermost pleistocene shrews (Mammalia, Soricidae) from Vaskapu Cave (N-Hungary). - Annales Universitatis Scientiarum Budapestinensis, Sectio Geologica, 32, pp. $49-56$.

Mészáros, L.Gy. 2004: Taxonomical revision of the Late Würm Sorex (Mammalia, Insectivora) remains of Hungary, for proving the presence of an alpine ecotype in the Pilisszántó Horizon. - Annales Universitas Scientiarum Budapestinensis, Sectio Geologica, 34, pp. 9-25.

Shipman, P., W. Bosler, K.L. Davis 1981: Butchering of Giant Geladas at an Acheulian site. - Current Anthropology, 22/3, pp. 257-268.

Válóczi, T. 1999: A Vaskapu-barlang (Bükk-hegység) felső pleisztocén faunájának vizsgálata. [Investigation of the Upper-Pleistocene fauna of Vaskapu-Cave (Bükk Mountains)]. - Folia Historico Naturalia Musei Matraensis, 23, pp. 79-96. 